\title{
How does Investment in energy affect the energy utilization-growth-tourism nexus? Evidence from E7 Countries
}

\begin{tabular}{|c|l|}
\hline Journal: & Energy and Environment \\
\hline Manuscript ID & EAE-20-0459.R2 \\
\hline Keywscript Type: & Original Article \\
\hline Keywords: & $\begin{array}{l}\text { Tourism, , Energy Utilization, Economic growth, C02 emissions, E7 } \\
\text { States, , Investment in energy sector }\end{array}$ \\
\hline Abstract: & $\begin{array}{l}\text { Tourism is an important driver of economic growth for several countries } \\
\text { in the world. However, the rise in tourism activities has raised concerns } \\
\text { regarding emissions resulting from tourist activities such as } \\
\text { transportation as well as the consequent effect on the quality of the } \\
\text { environment. Hence, this study examines the impact of tourism and } \\
\text { other factors such as investments, energy utilization and economic } \\
\text { growth on CO2 pollution in the emerging seven countries (China, India, } \\
\text { Brazil, Mexico, Russia, Indonesia and Turkey) for the period 2000 to } \\
\text { 2018. The study uses the PMG-ARDL, OLS, DOLS and FMOLS estimators } \\
\text { and Dumitrescu and Hurlin Causality Test. Long run regression estimates } \\
\text { reveal that a rise in tourism activities lower C02 emissions in the E7 } \\
\text { countries which can be traced to the adoption of environmentally friendly } \\
\text { tourism. As for investments and economic growth, the majority of the } \\
\text { regression results point that both factors lower CO2 emissions in the E7 } \\
\text { countries while Energy consumption is a driver of CO2 emissions in the } \\
\text { E7 countries. The study suggests that the implementation of } \\
\text { environmentally friendly tourism be sustained so as to continually } \\
\text { improve the quality of the natural environment in the blocs. Similarly, } \\
\text { strict regulation of economic activities in line with the protection of the } \\
\text { environment is advised while the use of renewable energy is needed to } \\
\text { reduce emissions in the E7 countries. }\end{array}$ \\
\hline
\end{tabular}

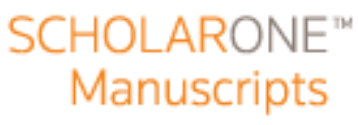




\title{
How does energy investment affect the energy utilization-growth-tourism nexus? Evidence from E7 Countries
}

\begin{abstract}
Tourism is an important driver of economic growth for several countries in the world. However, the rise in tourism activities has raised concerns regarding emissions resulting from tourist activities such as transportation as well as the consequent effect on the quality of the environment. Hence, this study examines the impact of tourism and other factors such as investments, energy utilization and economic growth on carbondioxide $\left(\mathrm{CO}_{2}\right)$ emission in the emerging industrialized seven countries namely (China, India, Brazil, Mexico, Russia, Indonesia and Turkey) for the period 2000 to 2018. The study uses the Pool Mean Group Autoregressive Distributed Lag (PMG-ARDL), ordinal least square (OLS), dynamic ordinals least square (DOLS) and fully modified least square (FMOLS) estimators as well as Dumitrescu and Hurlin Causality Test. Long run regression estimates reveal that a increase in tourism activities lower carbondioxide emissions in the E7 countries which can be traced to the adoption of environmentally friendly tourism. Furthermore, investment in energy and economic growth, the majority of the regression results point that both factors lower carbondioxide emissions in the emerging seven (E7) countries while energy consumption is a driver of $\mathrm{CO}_{2}$ emissions in the E7 countries. The study suggests that the implementation of environmentally friendly tourism be sustained to continually improve the quality of the natural environment in the blocs. Similarly, strict regulations of economic activities in line with the protection of the environment are advised while the use of renewable energy is needed to reduce emissions in the E7 countries.
\end{abstract}

Keywords: Tourism, Energy Utilization; Environmental sustainability; Economic growth; carbondioxide emissions, Investment in the energy sector; E7 economies 


\section{Introduction}

Globally, tourism is perceived to be the gateway for economic sustainability to many regions. In the past couple of decades, the tourism market has emerged as a sunshine business and is known to be one of the main sectors, both in emerging and stable countries. To support this assertion, Paramati, Shahbaz and Alam (2017) documented the findings from the World Tourism Organization, which proofs that tourism is the largest market in all the tourist countries. Also, Alam and Paramati (2016) confirmed that tourism industry encourages expansion in the economy through forex remunerations, overseas spending, improved tax collections, and new investment possibilities. Forex income from tourism operations, especially in an emerging economy, is a significant source of external funding for the acquisition of goods and services and financing other important infrastructure activities to expand the economy of the country. Similarly, several documentations show that the tourist industry has become a very effective driver for trade and industry and social development (Balsalobre-Lorente et al., 2020; Etokakpan et al., 2019; Eyuboglu and Eyuboglu, 2019; Frleta and Jurdana, 2017; Roudi, Akadiri and Arasli, 2018; Tugcu, 2014). The highest benefit of the tourism industry is creating new jobs and developing the hospitality-associated sectors which have a huge impact on the economy (Li et al., 2016: MacNeill \& Wozniak, 2018; Li et al.,2019; Lu et al.,2019; Godwin and Walpole, 2000; Zurub et al., 2015). Based on the aforementioned impact of tourism on the world economy, its extension is considered a crucial area for economic and social expansion (Brida and Risso, 2009; Tang and Tan, 2013). But, the expansion of the tourist industry leads to an increase in consumption of energy such as fossil, coal, natural gas, and in important greenhouse gas emission (GHG). The exponential increase in the tourism and airline industries have affected the markets of many developing countries in different ways. However, investment in the energy sector may generate an outstanding return within a short period. Additionally, healthy and friendly environment is promoted by a large proportion of tourist travellers (United Nations Environment Program 2011). This reason is the rationale behind this research which aimed to examine the nexus between tourism and energy investment as well as other economic variables.

While the tourism sector is playing all this critical role in the economic as well as social development and poverty reduction, in the past couple of years, the tourism industry has created ecological damage 

in 1968 fell to 13,017,193.6 kilotons (kt), which rose to nearly 300 per cent in 2014 to 36,138,285 kt. The greater degree of global issues is an anthropogenic worldwide heating due to extraordinary $\mathrm{CO}_{2}$ pollution which puts massive pressure on planners. Consequently, the elimination of global $\mathrm{CO}_{2}$ pollution and the development of sustainable human-carbon economies are now an urgent target on the planet. Researchers have recently begun to investigate possible areas regarding tourism and $\mathrm{CO}_{2}$ pollution, and perhaps even the connection of tourism to overall $\mathrm{CO}_{2}$ pollution. Relative to the global standards

Upon all these numerous benefits, the percentage of the tourism sector to the entire pollutant in 2002, 2005, 2007 and 2010 was roughly 2.489 per cent, 2.425 per cent, 2.439 per cent, and 2.447 per cent respectively collectively in China which is the largest economy among the E7 countries (Meng et al., 2016). Unintended greenhouse gas emissions from the tourism industry (except for the transport sector) have been estimated to be 3 to 4 times higher than their specific $\mathrm{CO}_{2}$ pollution (Meng et al., 2016). Relative to global standards, China's tourism-related $\mathrm{CO}_{2}$ pollution contributes to a lower share of total manufacturing pollution. Nevertheless, despite China's tremendous greenhouse gasses which is roughly 9.123 billion tons in 2016, responsible for 27.3 per cent of the world's pollution, as per the BP Statistical Analysis of Global Energy for June 2017, only about 2.5 per cent of the total pollution will be responsible for tourist, which mean that perhaps the tourism sector is sensitive.

However, this study was carried out to fill these gaps by exploring the linkage between the tourism industry and pollutant emission in E7 countries over the period of 2000 to $2018^{1}$. Economic activities and energy consumption and privately-owned spending in energy, international tourism arrival are both used in the model as control variables in a carbon-income function framework. The E7 economies are selected to examine the relationship regarding tourism and pollutant emissions as they are major global tourist attractions in recent times. The rare ecological and historic cities within the E7 nations like cities in Turkey draw a considerable number of visitors to these communities annually. Nevertheless, these countries do have extraordinary pollutants of $\mathrm{CO}_{2}(\mathrm{Ozturk}$ and Acaravc1, 2010). Statistics from the Global Carbon Atlas indicates that all these countries are among the largest sources of $\mathrm{CO}_{2}$ pollution in the world in 2016. Essentially, E7 participants are not just a major visitor's

${ }^{1}$ E7 Countries: Group of seven economies on a fast pace of economic trajectory namely: Brazil, Russia, India, China, Indonesia, Mexico and Turkey, which are all mostly emerging and newly industrialized nations 
destination, but also countries containing excessive rates of $\mathrm{CO}_{2}$ emissions. The ongoing collaboration concerning tourism and pollutant emissions is very vital to the development of hospitality and ecofriendly legislation. This study examines the influence of tourism, real GDP, energy utilization and investment in the energy sector on emissions in the E7 countries. As shown in the literature of related studies numerous findings have been carried out in this sector. For the first time, we attempt to focus on the case of newly industrialized and emerging E7 economies which have received little or no documentation in the extant literature. The importance of carrying out this study in the E7 blocs can be traced to the following First, the E7 countries are among the top tourist destinations on the globe. Secondly, the E7 is one of the highest global emitters of $\mathrm{CO}_{2}$ in the world and is an area that is responsible for the second-highest contribution to GDP in the world (Gyamfi et al.,2020a, Bekun and Gyamfi, 2020c). However, to know the influence of the tourist sector on emissions in this bloc will help in no small way in pursuing a global reduction in $\mathrm{CO}_{2}$ emissions in the natural environment and a healthier living environment. The main findings highlight a long-run equilibrium relationship between the highlighted variables. Long run regression estimates reveal that a rise in tourism activities lower $\mathrm{CO}_{2}$ emissions in the $\mathrm{E} 7$ countries which can be traced to the adoption of environmentally friendly tourism. Furthermore, investment in energy and economic growth, the majority of the regression results point that both factors lower $\mathrm{CO}_{2}$ emissions in the $\mathrm{E} 7$ countries while energy consumption is a driver of $\mathrm{CO}_{2}$ emissions in the $\mathrm{E} 7$ countries. To the best of our knowledge, this research is the first of its kind to apply a battery of econometric strategies such as the dynamic panel OLS, DOLS and FMOLS, PMG-ARDL as well as the Heterogeneous causality test to examine the tourism-energy investment nexus in emerging countries (E7). Hence, series of objectives to be obtained in this study includes but not limited to complementing and adding to the significant of the previously reviewed literature, examining the nexus between the tourism and $\mathrm{CO}_{2}$ pollution in E7 countries. It is also expected that the findings of the analysis will be a crucial focal point for energy stakeholders and policymakers by making a proper investment in the tourist energy sector. It will also as a blueprint for another region.

The remaining sections in the study are structured as follows. Section 2 outlines the systematic review. Section 3 lays out the data and techniques used in the study. The results are set out in Section 4 . While section 5 outlines the concluding remarks and policy implications accordingly 


\section{Literature on Related studies}

Tourism leads favourably, more than anything, to growth in the economy. Nevertheless, economic and ecological implications of tourism cannot be overlooked, but it is essential to consider the complicated history involving economic development, tourism and $\mathrm{CO}_{2}$ pollution. Previous research directly investigates the interaction regarding tourism and economic development and the nature of the climate, such as $\mathrm{CO}_{2}$ pollution. This section splits the preceding research into three sub-sections: (i) report on Tourism and $\mathrm{CO}_{2}$ emissions; (ii) Economic growth and $\mathrm{CO}_{2}$ pollution; and (iii) Energy utilization and $\mathrm{CO}_{2}$ pollution

\subsection{Tourism and $\mathrm{CO}_{2}$ emissions}

Tourism already harms environmental sustainability in both emerging and advanced states (Leon et al., 2014; Robaina-Alves et al., 2013: Sarpong et al. 2020). The emergence of $\mathrm{CO}_{2}$ pollution from the tourist industry is appealing to academics. The research is split into binary fields of thinking on the involvement of leisure industry production in $\mathrm{CO}_{2}$ pollution. One organization claimed that tourism has a strong consequence on $\mathrm{CO}_{2}$ pollution. In the same way, Katircioglu (2014) confirms the longstanding as well as short-range connection regarding leisure industry and $\mathrm{CO}_{2}$ pollution in Turkey. Inferential statistics indicate that the leisure industry speeds up the production rate of $\mathrm{CO}_{2}$. Ragab and Meis (2016) proposed additional benefit of leisure industry specifically discharges 464.3 tons of $\mathrm{CO}_{2}$ pollution. Saenz-de-Miera and Rossello (2014) explain the interaction with tourism as well as air quality in Mallorca (Spain). Applying the wavelet-constructed style, Raza et al. (2016) argue how tourism, as well as its growth, have greatly led to ecological destruction in the United States. Solarin (2014) argues that visitor arrivals; actual GDP, oil use, financial growth and urbanization are responsible for $\mathrm{CO}_{2}$ pollution. Also, Al-Mulali et al. (2015) empirically explore how the tourism industry will limit $\mathrm{CO}_{2}$ pollution and reduce environmental degradation in EU countries. Gossling (2002) indicated how fossil fuel usage in the tourism industry and soil depletion has worsened ecological issues, such as anthropogenic climate change, by rising $\mathrm{CO}_{2}$ pollution. Peeters and Dubois (2010) estimated that tourism and leisure operations, such as travel and lodging, contribute $4.4 \%$ of overall $\mathrm{CO}_{2}$ pollution. The heavy energy intake in the tourism sector is the travelling area and it produces a large volume of $\mathrm{CO}_{2}$ pollution. Roughly 90 per cent of energy usage in the tourism and transit industries is attributed to aviation, 43 per cent to the road, 42 per cent to and sea and rail, and 15 per cent to transport 
(Higham et al 2016; Isik et al., 2017). Experts may assume how intense resource usage and habitat loss in the tourism area has had a major impact on $\mathrm{CO}_{2}$ pollution. On the contrary, the United Nations Environment Program (UNEP, 2008) publicized that tourist industry development, as well as environmental conservation, could never be used as conflicting forces. The incorporation of environmentally-pleasant technologies and green energies into tourist industry activities would reduce the harm to the earth, rendering the justifiable leisure industry feasible (Roxas et al., 2018).

Throughout tourist industry finances research, previous research has typically concentrated on the consequence of tourist industry on trade and industry and social development (Balaguer and Cantavella-Jorda, 2002; Durbarry, 2004; Brida et al., 2016; Dogru \& Bulut, 2018; Eyuboglu and Eyuboglu, 2019) employment formation (Andriotis and Vaughan, 2004; Walpole and Goodwin, 2000; Zurub et al., 2015), as well as deprivation (Llorca-Rodríguez, García-Fernández, 2015). While these reports have made a major contribution to recognizing the effects of tourism, most have not investigated much on the encouragement of the tourist industry on $\mathrm{CO}_{2}$ pollution. The crucial degree of ecological issues, in the form of anthropogenic global warming caused by high $\mathrm{CO}_{2}$ pollution, has made it necessary to explore the factors that contribute to these issues. While indicators such as growth in the economy, energy utilization, overseas investment, financial development and urbanization were used in investigating the factors that contribute to $\mathrm{CO}_{2}$ pollution, they did not concentrate the on tourism industry (Bekhet et al., 2017; Gokmenoglu and Taspinar, 2016; Shahbaz, Tiwari, and Nasir, 2013). In the span 1998Q1-2015Q4, Gozgor and Can (2017) explored the role of insecurity on the tourism expenditure of US domestic tourists. Economic Policy Volatility indicator was utilized as a predictor variable in tourism market assessment frameworks. Unit root and cointegration checks were introduced to accommodate for unexplained systemic fractures. The empirical results showed that a higher degree of Economic Policy Instability contributes to substantial decreases in tourism expenditure in the long run.

A further party reports that tourism has an indirect influence on the production of $\mathrm{CO}_{2}$. For instance, Lee and Brahmasrene (2013) argue that tourism boosts economic expansion but helps shrink $\mathrm{CO}_{2}$ pollution. Salih Turan Katircioglu et al. (2014) analyzed the interaction involving energy consumption, leisure industry metrics and greenhouse releases in Cyprus. The findings have shown that the leisure industry has a beneficial effect on total power utilization and pollutant pollution. In accumulation, DeVita et al., (2015) back the presence of EKC within Turkish economy, particularly given the importance of the leisure industry within. Generally speaking, from either the leisure industry $-\mathrm{CO}_{2}$ 

that capital expenditure in the tourism business and globalization are important considerations that can substantially reduce $\mathrm{CO}_{2}$ pollution and promote green tourism.

\subsection{Economy growth and $\mathrm{CO}_{2}$ Pollution (EKC Concept)}

Multiple experiments have documented the connection involving energy production and $\mathrm{CO}_{2}$ pollution in various geographical regions (Adedoyin et al. 2020a; Adedoyin et al. 2020; Bekun et al. 2019a; Bekun et al. 2019b; Anatasia, 2015; Kalayci and Koksal, 2015; Kapusuzoglu, 2014b; Katircioglu et al. 2014; Katircio, 2014; Katircicoglu et al. 2016; Gyamfi et al. 2020a, Gyamfi et al. 2020b). Al-Mulali et al. (2015) and Dogan and Seker (2016b) explore the differentiator of $\mathrm{CO}_{2}$ pollution in Eurozone (EU) states and obtained a positive connection regarding them. From Dogan and Seker (2016c), $\mathrm{CO}_{2}$ pollution indicators are assessed for the highest sustainable nations which were positively related. Also, Paramati et al. (2017) evaluate the lengthy-term connection regarding clean energies, economic production and environmental security and obtain a positive relationship between environmental development and pollution. Additionally, Fang et al., (2019) study based on the panel dataset of 82 emerging nations for the duration 1970 to 2014. The findings revealed a positive effect on $\mathrm{CO}_{2}$ pollutions from the quality of exports. The per capita income and $\mathrm{CO}_{2}$ reductions have both had a fair deal of positive impact. Additionally, trade transparency initiatives have been directly linked to emissions of $\mathrm{CO}_{2}$. These findings have been rigorous to take account of various tax metrics and to split the developed countries by profits. The different indicators of $\mathrm{CO}_{2}$ pollution are evaluated for OECD nations (Dogan and Seker, 2016a; Shafiei and Salim, 2014). Ali et al. (2017a, 2017b) investigated the association regarding sustainable development and pollutants and obtained a negative association among them. However, Dogan and Inglesi Lotz, (2017) analyzes the impact of living standards and biomass utilization on $\mathrm{CO}_{2}$ pollution and obtained a negative relationship among them. Multiple experiments have examined the correlation respectively growth and $\mathrm{CO}_{2}$ pollution across all predictors; further precisely, the EKC concept is extensively discussed. Illustration from (Jebl et al, 2016; Emir and Bekun,2019) measures ECC in OECD communities. Heidari et al (2015) are validating the EKC throughout ASEAN communities. Katircioglu and Taspinar (2017) say that considering the value of the financial growth respectively, the ECK operates within Turkey. 


\subsection{Energy Utilization and $\mathrm{CO}_{2}$ Pollution}

The interaction regarding energy use and $\mathrm{CO}_{2}$ pollution has always been the key topic of debate in the power and climate change establishment for centuries. This publication is separated into two parts. The very first segment refers to the correlation respectively economic progress and energy request and the next segment refers to the association among energy request and $\mathrm{CO}_{2}$ releases. Either the lines of publications of their advocates as well as most of the studies have demonstrated positive ties among both. Effective operations of any community are made up of the agriculture, industrial and services parts of the economy, which require the use of power supplies to deal with the speed of global fiscal growth. Such energy supplies used throughout the manufacturing cycle are primarily non-renewable and ozone-intensive and release a large proportion of GHGs into the ecosystem, thereby compromising the sustainability of the climate and man life on this planet. In this respect, Zhang and Cheng (2009) find that GDP induces energy usage in addition to long-term ecological emissions triggered by energy usage. An analysis of 8 Asia-Pacific countries, Meng and Niu (2011) noticed that there is still a lengthy-term affiliation regarding $\mathrm{CO}_{2}$ production, power usage and sustainable expansion. Analogously, in a survey of 27 progressive nations, Saboori and Sulaiman (2013) reported a bi-directional correlation between energy usage in the transportation market, transport by $\mathrm{CO}_{2}$ pollution and economic development. Also, Saboori and Sulaiman (2013) investigated the clear positive association regarding $\mathrm{CO}_{2}$ pollution and energy use both within the long and short term, by applying the ARDL and Granger causality technique in the VECM panel evidence from Southeast Asian jurisdictions. Also, statistical analysis results from the UAE directed via Sbia et al. (2014) showed that there is a positive link among power usage and sustainable expansion, even though there is a negative correlation among $\mathrm{CO}_{2}$ pollution and energy use. In the case of Nigeria, Akpan and Akpan (2012) have shown that economic development is one of the key drivers of the rise in $\mathrm{CO}_{2}$ pollution due to the rise in energy use. In comparison, Ali et al. (2017a, 2017b) studied the EKC throughout the context of Malaysia and hypothesized that power use and economic development are primary drivers of $\mathrm{CO}_{2}$ pollution. It also indicated that there was a feedback causal association regarding $\mathrm{CO}_{2}$ pollution and energy usage, whereas economic activity as well as other unidirectional factors caused by Granger $\mathrm{CO}_{2}$ pollution. Also, Pao and Tsai (2010) find that long-term $\mathrm{CO}_{2}$ concentrations are inelastic to production, whereas power demand remains elastic. The findings also demonstrate the existence of feedback causality. From the other perspective, Lotfalipour et al. (2010) asserted 


\section{Data and Methods}

\subsection{Data and Variables}

Data

The yearly information used in this study covers the period from 2000 to $2018^{2}$ for the E7 nations namely (China, India, Brazil, Mexico, Russia, Indonesia and Turkey). The variables considered include $\mathrm{CO}_{2}$ emissions, investments in energy utilization, Real GDP per capita and Energy Consumption and tourism receipt. As indicated in Table 1, data are sourced from the World Bank development indicators database (World Bank, 2019).

\footnotetext{
${ }^{2}$ Data framework is limited to availability of data in WDI for the investigated economies (E7) 
Table 1. Description of Variables

\begin{tabular}{|c|c|c|c|}
\hline Name of Indicator & Abbreviation & $\begin{array}{l}\text { Proxy/Scale of } \\
\text { Measurement }\end{array}$ & Source \\
\hline $\begin{array}{l}\text { Carbon dioxide } \\
\text { emissions per } \\
\text { capita }\end{array}$ & $\mathrm{CO}_{2}$ & $\begin{array}{l}\text { measured in metric } \\
\text { tonnes }\end{array}$ & WDI \\
\hline $\begin{array}{l}\text { Investment in } \\
\text { energy with } \\
\text { private } \\
\text { participation }\end{array}$ & INVT & current US\$ & WDI \\
\hline $\begin{array}{l}\text { Real GDP per } \\
\text { capita }\end{array}$ & GDP & $\begin{array}{l}\text { Constant } 2010 \\
\text { US\$ }\end{array}$ & WDI \\
\hline Tourist Arrivals & 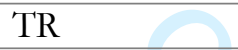 & Number of arrivals & WDI \\
\hline Energy Use & $\mathrm{EU}$ & $\begin{array}{l}\mathrm{kg} \text { of oil equivalent } \\
\text { per capita }\end{array}$ & WDI \\
\hline \multicolumn{4}{|c|}{$\begin{array}{l}\text { Note. WDI is a connotation for data from World Bank Development (WDI) Indicator of the World } \\
\text { Bank database sourced from https://data.worldbank.org/. }\end{array}$} \\
\hline
\end{tabular}

Table 2 shows summary statistics of the variables in the study. LNTR has the highest average value, Median and single highest value. While LNINVT is the most dispersed among the variables in the study. Also, LNGDP, LNINVT and LNTR are negatively skewed while $\mathrm{LNCO}_{2}$ and LNEC are positively skewed. While LNEC has the highest number of observations above its average value. The Jarque-Bera statistics reveal that the data is normally distributed. On the other hand, the correlation matrix reported in Table 3 shows that the variables under consideration LNGDP, LNEC, and LNT, have a positive connection with the dependent variable $\mathrm{LNCO}_{2}$ but $\mathrm{LNINVT}$ has a negative association with the dependent variable $\mathrm{LNCO}_{2}$.

Table 2. Summary Statistics

\begin{tabular}{|l|c|c|c|c|c|}
\hline & LNCO $_{2}$ & LNGDP & LNEC & LNTR & LNINVT \\
\hline Mean & 1.221945 & 8.618614 & 7.231252 & 23.24567 & 21.22430 \\
\hline Median & 1.259618 & 9.082865 & 7.270205 & 23.27279 & 21.39303 \\
\hline Maximum & 2.548271 & 9.620394 & 8.550050 & 24.66803 & 24.26349 \\
\hline Minimum & -0.036378 & 6.717312 & 6.030720 & 21.33520 & 14.91412 \\
\hline Std. Dev. & 0.721218 & 0.810094 & 0.648203 & 0.774598 & 1.640357 \\
\hline Skewness & 0.251307 & -0.823919 & 0.370998 & -0.176809 & -0.983067 \\
\hline Kurtosis & 2.110579 & 2.345692 & 2.765109 & 2.383202 & 4.601334 \\
\hline Jarque-Bera & 5.783788 & 17.42018 & 3.356764 & 2.801230 & 35.63266 \\
\hline Probability & 0.055471 & 0.000165 & 0.186676 & 0.246445 & 0.000000 \\
\hline
\end{tabular}




\begin{tabular}{|l|l|l|l|l|l|}
\hline VARIABLES & LNCO2 & LNGDP & LNEC & LNTR & LNINVT \\
\hline LNCO2 & 1.000000 & & & & \\
\hline p-value & - & & & & \\
\hline LNGDP & $0.632855^{* * *}$ & 1.000000 & & & \\
\hline p-value & $(0.0000)$ & - & & & \\
\hline LNEC & $0.956250^{* * *}$ & $0.733703^{* * *}$ & 1.000000 & & \\
\hline p-value & $(0.0000)$ & $(0.0000)$ & ----- & & \\
\hline LNTR & $0.456136^{* * *}$ & 0.116715 & $0.240175^{* * *}$ & 1.000000 & \\
\hline p-value & $(0.0000)$ & $(0.1809)$ & $(0.0054)$ & ---- & \\
\hline LNINVT & $-0.27647^{* * *}$ & -0.002264 & $-0.23697^{* * *}$ & 0.045551 & 1.000000 \\
\hline p-value & $(0.0013)$ & $(0.9794)$ & $(0.0060)$ & $(0.6026)$ & ---- \\
\hline
\end{tabular}

Note: ${ }^{* * *},{ }^{* *}$ and $*$ are $1 \%, 5 \%$ and $10 \%$ significant level respectively

\subsection{Models and Methods}

This analysis sets to identify the influence of tourism, real GDP, energy utilization and investment in the energy sector on emissions in the E7 countries. As shown in the literature of related studies numerous findings have been carried out in this sector. For the first time, we attempt to focus on the case of newly industrialized and emerging E7 economies which have received little or no documentation in the extant literature. The importance of carrying out this study in the E7 blocs can be traced to the following First, the E7 countries are among the top tourist destinations on the globe. Secondly, the E7 is one of the highest global emitters of $\mathrm{CO}_{2}$ in the world and is an area that is responsible for the second-highest contribution to GDP in the world (Gyamfi et al.,2020a). However, to know the influence of the tourist sector on emissions in this bloc will help in no small way in pursuing a global reduction in $\mathrm{CO}_{2}$ emissions in the natural environment and a healthier living environment.

This analysis considers the position of tourism, real GDP per capita, energy intake and investment in the energy sector on $\mathrm{CO}_{2}$ pollution and the development of the EKC proposes the following model equations: 


$$
\mathrm{LNCO}_{2}=f(L N G D P, \text { LNTR, LNINVT, LNEC) }
$$

LNC02

$$
=\alpha_{0}+\beta_{1} L N G D P_{i t}+\beta_{2} L N T R_{i t}+\beta_{3} L N I N V T_{i t}+\beta_{4} L N E C_{i t}+\varepsilon_{i t}
$$

Logarithmic transformation of all variables has been performed to enable the study variables to maintain constant va Consequently, four estimation techniques are utilized in this study, OLS, FMOLS, DOLS, and the Pooled Mean Gro The DOLS is estimated using Eq 2. which is given as:

$$
\begin{aligned}
& L N C 02_{i t}=\mu_{i}+x_{i, t} \Psi_{i, t}+\sum_{j=-p}^{p} \beta_{j} L N C 02_{i . t-j}+\sum_{j=-q 0}^{q 0} p_{1 . j} L N T R_{i . t-j}+p_{2 . j} \sum_{j=-q 1}^{q 1} L N E C_{i . t-j} \\
& +p_{3 . j} \sum_{j=-q 2}^{q 2} L N G D P_{i . t-j}+p_{4 . j} \sum_{j=-q 3}^{q 2} L N I N V T_{i . t-j}+\varepsilon_{i t}
\end{aligned}
$$

$p$ and $q$ are the numbers of leads/lags. The long-run connection is estimated from the FMOLS equation given as:

$\mathrm{LNCO}_{2}=\mu_{i}+x_{i . t} \psi+v_{i t}$

$x_{i . t}=x_{i . t}+\mathfrak{C}_{i . t}$

Where $x \quad 5^{*} 1$ vector of explanatory variables is, $\mu_{i}$ is the intercept while $\mathfrak{C}_{i . t}$ and $v_{i t}$ are the error terms. However, the estimation of $\psi$ is expressed as:

$$
\begin{aligned}
& \hat{\psi}_{F M O L S}=\left(\sum_{i=1}^{N} \sum_{t=1}^{T}\left(x_{i . t}-\bar{x}_{i . t}\right) *\left(x_{i . t}-\bar{x}_{i . t}\right)^{\prime}\right)^{-1} *\left(\sum_{i=1}^{N}\right. \\
& \left.\left(\sum_{t=1}^{T}\left(x_{i . t}-\bar{x}_{i . t}\right) * L \widehat{N C 0} 2_{i t}-T \hat{\Delta}_{v \mathfrak{C}}\right)\right)
\end{aligned}
$$

The researchers also examined both short-and long-term forecasts utilizing the Pesaran et al. (1999) method. The study proceeded with the evaluation of agricultural value added-GDP-Energyemissions nexus identified in Eq. (1) in the Autoregressive Distributed Lag (ARDL: p, q) system that integrates all pollution lags including Regressors, provided that:

$$
L N C 02_{i t}=\beta_{i}+\sum_{j=0}^{p} \delta_{i j} L N C O 2 Z_{i t-j}+\sum_{j=1}^{q} \varphi \delta_{i, j} Z_{i t-j}+\varepsilon_{i t}
$$


Where, $\mathrm{Z}_{\mathrm{it}}=\left(\mathrm{LNTR}_{\mathrm{it}}, \mathrm{LNEC}_{\mathrm{it}}, \mathrm{LNGDP}_{\mathrm{it}}, \mathrm{LNINVT}_{\mathrm{it}}\right)$ this is a function for the explanatory variables used in this analysis. $\beta \mathrm{i}$ indicates the country-level fixed results, $\delta i j$ indicates the slope of the lagged pollution vector and $\varphi \mathrm{i}, \mathrm{j}$ indicates the slope of the lagged control variables.

The PMG-ARDL co-integration methodology has important econometric strengths relative to conventional panel data models. It could fix endogeneity problems in econometric models and at the same time handle either short-or long-term parameters. The ARDL co-integration method is also capable of taking into account variables in a combined integration order, such as I(0) or/and I (1) but not I (2). Pesaran et al. (1999) also reported that the Pool Mean Group (PMG) estimator is accurate, resilient and high to lag orders and outliers.

\section{Results and Discussions}

\subsection{Pre-estimation Diagnostics}

\section{Unit Root and Cointegration tests}

We report the result for unit root using the Augmented Dicker-Fuller and Philips Perron unit root tests as presented in Table 4 bases on the unit root estimations from the Gozgor, (2016). All variables are first difference stationary. At level one variable and two variables were stationary without trend and with trend respectively based on both unit-roots. Furthermore, we employ Carrion-i-Silvestre et al.(2005)-Panel stationarity that allows for the presence of multiple structural breaks. The highlighted break dates resonates with key economic and political events and episodes in the investigated blocs ${ }^{3}$. However, given that all variables are stationary at the first difference we then concluded that the variables are stationary.

To test for cointegration, we adopted the Pedroni and Kao tests of cointegration. Results from the Pedroni test (table 5) shows that all variables have a cointegrating relationship under the conditions of deterministic intercept and trend and no deterministic trend, but not for no deterministic intercept and trend. On the other hand, the Kao (table 6) discloses that there is a cointegrating association regarding the variables. Hence, we conclude that there is a cointegrating association regarding the variables $\mathrm{LNCO}_{2}$, LNGDP, LNTR, LNINT and LNEC.

\footnotetext{
${ }^{3}$ For the brevity of space, the results of the difference Silvestre et al.(2005)-Panel stationarity is appended at the appendix section.
} 
7

8

9 VARIABLES

$\mathrm{LNCO}_{2}$

LNGDP

1 LNTR

UNIT ROOT TEST

14NINVT

1ENEC

16

17

\section{Deterministic intercept and trend}

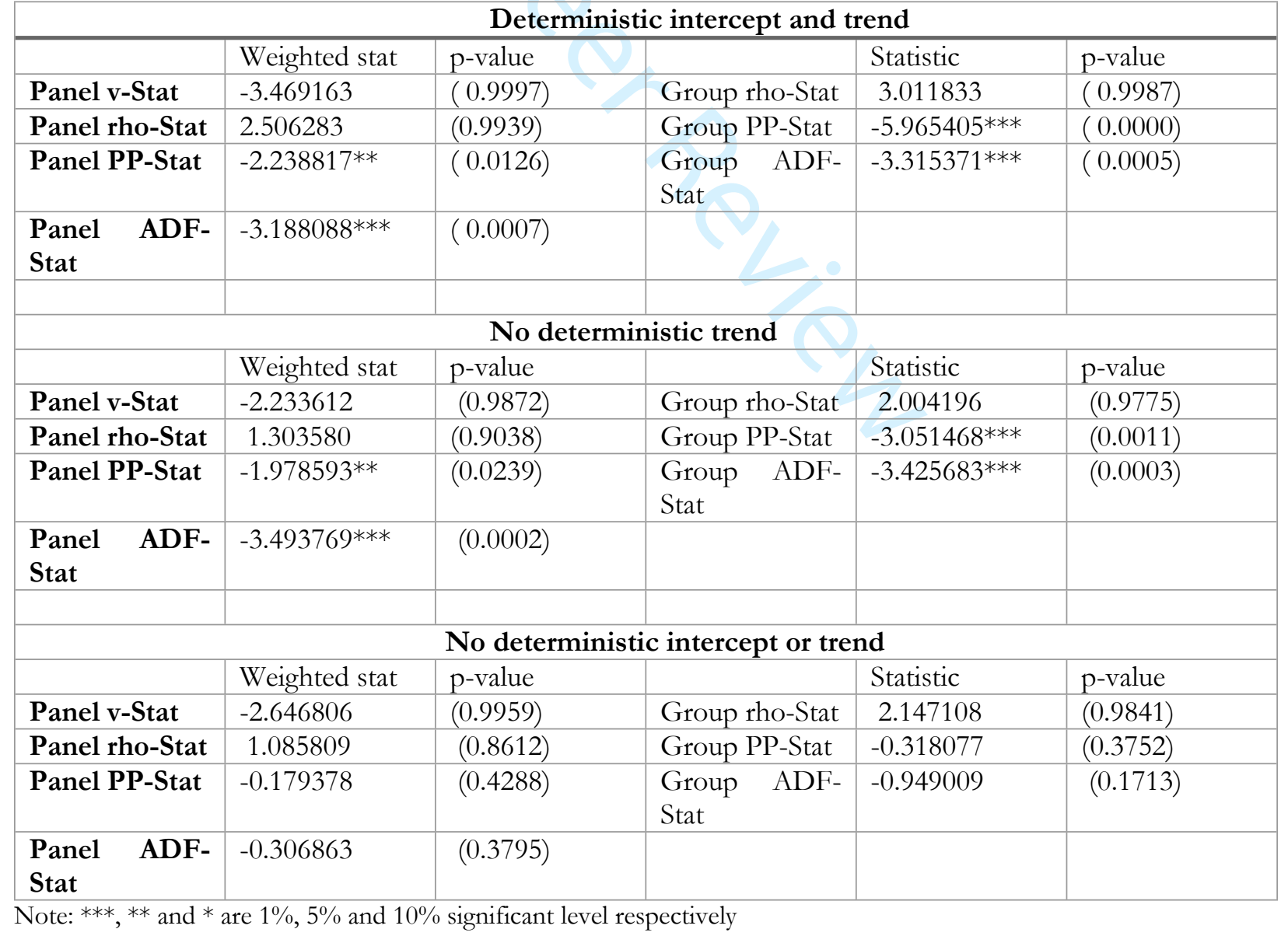




\section{Note: $* * *, * *$ and $*$ are $1 \%, 5 \%$ and $10 \%$ significant level respectively}

\subsection{Estimations}

Table 7 presents the result for the OLS, DOLS and FMOLS estimations. The outcomes proofs that the coefficient of LNGDP is predominantly positive and statistically significant which entails that the development of the economy has a positive and significant effect on $\mathrm{CO}_{2}$ pollution in the E7 countries. However, development of the economy harms $\mathrm{CO}_{2}$ in the OLS estimate which signifies that economic growth decreases pollutants in the study nations. A positive coefficient in LNGDP means that a rise in economic production in the E7 countries will lead to an increase in emissions. Specifically, a 1\% increase in LNGDP will lead to between $0.631 \%$ and $0.187 \%$ increase in emissions, this is in line with the study of Gyamfi et al., (2020a, c) The E7 is a bloc with huge economic activitiesbeing only second to the $\mathrm{G} 7$ in size of economic output as a share of global output (Gyamfi et al., (2020b). This finding is similar to that of Katircioglu and Tas upinar (2017) for Turkey and Heidari et al (2015) for ASEAN countries. The observed positive significant relationship between economic growth and $\mathrm{CO} 2$ emission. This suggests that economic growth enhances higher carbon emission in the investigated blocs. This is indicative of energy practitioners and stakeholders. Our empirical results also show a positive significant relationship between economic growth in the short and long-run. This is laudable for the study area been that they emerging and highly industrialized countries in nature in terms of economic activities where the emphasis is on increase growth relative to the quality of the environment (Shahbaz \& Sinha, 2019). However, there is a need to tighten environmental commitment like been a signatory to Kyoto Protocol and other energies treaties/regulations (Sarkodie et al.2020). Thus, it is argued that higher economic activities translate into higher $\mathrm{CO}_{2}$ emission to motivates the acquisition and the replacement of outmoded energy-consuming technologies to more energy-efficient technologies — energy conservation options, hence improving energy efficiency.

The findings illustrate that tourism has a negative impact on pollutant which entails that a rise in tourist activities lower emissions in the focus countries. Specifically, a 1\% rise in tourism lowers pollutant emission by $0.11 \%$. This result signifies the deliberate measures taken by the authorities to check tourism-related emissions in the regions. Such measures could include the adoption of non-emitting 
activities in the tourism sector in the E7 countries. Similar findings are documented in Katircioglu, (2014) for Cyprus.

The coefficient for investment is both negative and positive following the OLS and DOLS estimates respectively. This variation in result could be due to the inclusion of panel heterogeneities in the DOLS model. It, therefore, means that a rise in investments will give rise to emissions in the study countries. Specifically, a $1 \%$ increase in investments will lead to a $0.49 \%$ increase in emissions or a $1 \%$ fall in emissions depending on the respective choice of estimator between DOLS and OLS. These findings support those of Ajide and Adeniyi (2010) for Nigeria and Pao, and Tsai (2010) for BRICS countries.

From the other point of view, we find that increasing the use of energy in the E7 countries drives emissions upward. Specifically, a 1\% rise in energy use will propel emissions within the range of 8.93\% to $9.96 \%$. This signifies that there is significant use of combustible energy resources in the bloc and it entails a notable presence of non-renewable energy mix for the E7 countries. It is worthy of note that this bloc is home to more than 2 billion people hence there is a great consumption of energy not just for industrial use but for domestic use also. Similar findings have been documented by Meng and Niu (2011) for eight Asia-Pacific countries and Saboori and Sulaiman (2013) for 27 countries.

Table 7. Results from OLS, DOLS and FMOLS

\begin{tabular}{|l|l|l|l|}
\hline VARIABLES & OLS & DOLS & FMOLS \\
\hline LNGDP & $-0.133256^{* *}$ & $0.631144^{*}$ & $0.185614^{* *}$ \\
\hline p-value & $(0.0167)$ & $(0.0636)$ & $(0.0330)$ \\
\hline LNTR & $-0.115865^{* * *}$ & -0.028471 & 0.012558 \\
\hline p-value & $(0.0000)$ & $(0.8191)$ & $(0.6594)$ \\
\hline LNINVE & $-0.100472^{* * *}$ & $0.04924)^{*}$ & 0.000484 \\
\hline p-value & $(0.0000)$ & $(0.0610)$ & $(0.9269)$ \\
\hline LNEC & $0.996455^{* * *}$ & 0.466111 & $0.893290^{* * *}$ \\
\hline p-value & $(0.0000)$ & $(0.2193)$ & $(0.0000)$ \\
\hline R-SQUARE & 0.790296 & 0.998870 & 0.994026 \\
\hline ADJ R-SQUARE & 0.785419 & 0.992620 & 0.993506 \\
\hline
\end{tabular}

Note: ${ }^{* * *}, * *$ and $*$ are $1 \%, 5 \%$ and $10 \%$ significant level respectively

Table 8 presents short-run and long-run estimates obtained by the PMG-ARDL estimator. As can be seen, the results are consistent with previous studies but at different significant levels. We see that LNGDP has a negative and statistically significant coefficient in the long run while it has a nonsignificant coefficient in the short run. This entails that in the long run, as economic growth rises emissions in the $\mathrm{E} 7$ countries begin to fall. Specifically, a 1\% rise in LNGDP leads to a fall in emissions 
by $0.8 \%$ in the long run. A similar outcome is obtained when this same model was estimated by OLS estimator earlier in this study. This result entails that in the long as economic growth rises emissions reduce.

From the other perspective, tourism leads to a fall in pollutant in the long run as earlier outcomes in this study have shown. However, the short-run lagged coefficient of LNTR which is positive and significant implies that tourism activities in the previous year contribute to emissions in the current year. This outcome confirms that while tourism drives emissions in the short run, it reduces emissions after some time. This results are in support of efforts towards the realization of environmentally favourable tourism in the E7 nations in the long run and shows the commitment of the bloc to implement sustainable tourism over time such that a rise in tourism activities will reduce emissions thus paving way for an improvement in the quality of the environment.

Consequently, findings proofs that in the long run Energy use drives emissions even as earlier results in the study have shown. In the short run, energy use has no significant influence on pollutants. The long-run effect of energy use on pollution reveals that non-renewable power is significantly used to meet energy needs in the E7 countries hence it contributes to rising emissions in the region. In particular combustible energy such as coal is still actively used in countries like China for energy purposes, hence the resulting influence on pollutants.

The long-run coefficient for investment is negative and significant which suggests that a rise in investments also leads to a fall in pollutions in the long run. While investments have no effect on emissions in the short run, the long-run effect of investments on emissions in the selected countries have been earlier shown by results discussed earlier in the study. This outcome points us to the strict environmental regulations guiding investments in the E7 countries and implies that under strict regulations, business activities can reduce emissions in the environment and that increased economic activities can be attained alongside an improvement in the quality of the environment.

Table 8. Robustness Results from PMG-ARDL (1, 2, 2, 2, 2)

\begin{tabular}{|l|l|l|l|}
\hline \multicolumn{3}{|c|}{ LONG RUN EQUATIONS } \\
\hline VARIABLES & COEFFICIENT & STD. ERROR & t-STATISTIC \\
\hline LNGDP & $-0.081075^{* *}$ & 0.033781 & -2.400005 \\
\hline
\end{tabular}




\begin{tabular}{|c|c|c|c|}
\hline LNEC & $1.299647 * * *$ & 0.057325 & 22.67143 \\
\hline LNINVT & $-0.006906 * * *$ & 0.002017 & -3.423318 \\
\hline LNTR & $-0.053801 * * *$ & 0.014989 & -3.589273 \\
\hline \multicolumn{4}{|c|}{ SHORT-RUN EQUATION } \\
\hline VARIABLES & COEFFICIENT & STD. ERROR & t-STATISTIC \\
\hline COINTEQ01 & $-0.350077^{*}$ & 0.187919 & -1.862913 \\
\hline D(LNGDP) & 0.310126 & 0.479776 & 0.646397 \\
\hline D(LNGDP(-1)) & 0.083534 & 0.187220 & 0.446182 \\
\hline D(LNEC) & 0.544284 & 0.390686 & 1.393149 \\
\hline D(LNEC(-1)) & -0.092431 & 0.166344 & -0.555660 \\
\hline D(LNINVT) & 0.001497 & 0.002868 & 0.522158 \\
\hline D(LNINVT(-1)) & -0.000338 & 0.002634 & -0.128227 \\
\hline D(LNTR) & 0.006047 & 0.042336 & 0.142829 \\
\hline D(LNT(-1)) & $0.114223^{* *}$ & 0.055787 & 2.047480 \\
\hline $\mathbf{C}$ & $-2.080643^{*}$ & 1.118876 & -1.859583 \\
\hline
\end{tabular}

Note: $* * *, * *$ and $*$ are $1 \%, 5 \%$ and $10 \%$ significant level respectively

\subsection{Dumitrescu and Hurlin Causality Test}

Table 9 reports the heterogeneous causality test. Results show that there is no causality between $\mathrm{LNEC}$ and $\mathrm{LNCO}_{2}, \mathrm{LNCO}_{2}$ and LNINVT, LNGDP and LNINVT, LNINVT and LNEC, LNTR and LNINVT. There is unidirectional causality from LNGDP to $\mathrm{LNCO}_{2}, \mathrm{LNTR}$ to $\mathrm{LNCO}_{2}$, LNGDP to LNEC, LNGDP to LNT, and LNTR to LNEC. This result signifies that economic growth and tourism cause emissions directly. Also, economic growth causes energy consumption and tourism directly, while tourism also causes energy consumption directly. However, investments do not cause emissions.

Table 9. Heterogeneous Causality Test

\begin{tabular}{|c|c|c|}
\hline Null Hypothesis: & Zbar Stat & p-value \\
\hline $\mathrm{LNGDP} \neq \mathrm{LNCO}_{2}$ & $2.04957 * *$ & $(0.0404)$ \\
\hline $\mathrm{LNCO}_{2} \neq \mathrm{LNGDP}$ & -0.38538 & $(0.7000)$ \\
\hline $\mathrm{LNEC} \neq \mathrm{LNCO}_{2}$ & 0.92708 & $(0.3539)$ \\
\hline
\end{tabular}




\begin{tabular}{|c|c|c|}
\hline $\mathrm{LNCO}_{2} \neq \mathrm{LNEC}$ & -0.07065 & $(0.9437)$ \\
\hline LNTR $\neq \mathrm{LNCO}_{2}$ & $2.42772^{* *}$ & $(0.0152)$ \\
\hline $\mathbf{L N C O}_{2} \neq \mathbf{L N T R}$ & -0.03156 & $(0.9748)$ \\
\hline 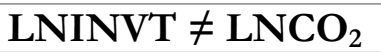 & -0.13333 & $(0.8939)$ \\
\hline $\mathbf{L N C O}_{2} \neq$ LNINVT & -0.16832 & $(0.8663)$ \\
\hline LNEC $\neq$ LNGDP & -0.80351 & $(0.4217)$ \\
\hline LNGDP $\neq$ LNEC & $1.89383^{*}$ & $(0.0582)$ \\
\hline LNT $\neq$ LNGDP & 2.06386 & $(0.0390)$ \\
\hline LNGDP $\neq$ LNT & $2.72610^{* * *}$ & $(0.0064)$ \\
\hline LNINVT $\neq$ LNGDP & 1.51848 & (0.1289) \\
\hline LNGDP $\neq$ LNINVT & 0.78954 & $(0.4298)$ \\
\hline LNTR $\neq$ LNEC & $1.95266^{*}$ & $(0.0509)$ \\
\hline LNEC $\neq$ LNTR & 1.03390 & $(0.3012)$ \\
\hline LNINVT $\neq$ L LNEC & -0.49272 & $(0.6222)$ \\
\hline LNEC $\neq$ LNINVT & -0.24695 & $(0.8050)$ \\
\hline LNINVT $\neq$ LNTR & 0.52131 & $(0.6022)$ \\
\hline LNTR $\neq$ LNINVT & 0.51216 & $(0.6085)$ \\
\hline
\end{tabular}

Note: $* *, * *$ and $*$ are $1 \%, 5 \%$ and $10 \%$ significant level respectively while $\neq$ denote does not "Granger cause"

\section{Concluding remarks and Policy Implementations}

Tourism is an essential determinant of economic growth for several countries in the world. However, the rise in tourism activities has raised concerns about the amount of pollutant resulting from tourist activities such as the construction of leisure facilities and transportation. However, previous studies have omitted the $\mathrm{E} 7$ countries which is among the top tourist destinations and top $\mathrm{CO}_{2}$ emitters in the world. Hence, this study was commissioned to investigate the tourism-growthemissions nexus in the region of the emerging seven countries namely China, India, Brazil, Mexico, Russia, Indonesia and Turkey for the period 2000 to 2018. The study employed the use of panel dynamic estimators such as the PMG-ARDL, DOLS and FMOLS estimators and the Dumitrescu and Hurlin Causality Test.

Findings from the study reveal that tourism activities lower $\mathrm{CO}_{2}$ emissions in the $\mathrm{E} 7$ countries which demonstrate that increased tourist activities are good for the improvement in the environmental quality of the E7 countries which affirms the findings of Katircioglu, (2014) for Cyprus as well as Dogan and Aslan (2017) for EU and candidate nations. This outcome is triggered by the adoption of environmentally friendly tourism in the region, whereby tourist activities minimize the use of combustible fuel. Similarly, the study finds that investments and economic growth lower $\mathrm{CO}_{2}$ 
emissions in the E7 countries affirming the findings of Ajide and Adeniyi (2010) for Nigeria and Pao, and Tsai (2010) for BRICS countries for investment, while the studies of Katircioglu and Taspinar (2017) for Turkey and Heidari et al (2015) for ASEAN countries affirms for the economic growth. These outcomes reveal the commitment of the regional government to pursue economic development without adverse impact on the natural environment through emissions. However, Energy consumption contributes to $\mathrm{CO}_{2}$ emissions in the $\mathrm{E} 7$ countries. The findings affirm the studies of by Meng and Niu (2011) for eight Asia-Pacific countries and Saboori and Sulaiman (2013) for 27 countries

From the short-run estimation of the ARDL, the result reviewed that coefficients of LNTR which is positive and significant imply that tourism activities in the previous year contribute to emissions in the current year. This outcome confirms that while tourism drives emissions in the short run, it reduces emissions after some time. This results are in support of efforts towards the realization of environmentally favourable tourism in the E7 nations in the long run and shows the commitment of the bloc to implement sustainable tourism over time such that a rise in tourism activities will reduce emissions thus paving way for an improvement in the quality of the environment. Energy used had no significant on pollutants. Again, investment also did not affect emission in the E7 countries. From the causality estimation, the result reviewed that, there was a unidirectional causality from LNGDP to $\mathrm{LNCO}_{2}, \mathrm{LNTR}$ to $\mathrm{LNCO}_{2}$, LNGDP to LNEC, LNGDP to LNT, and LNTR to LNEC. This result signifies that economic growth and tourism cause emissions directly. Also, economic growth causes energy consumption and tourism directly, while tourism also causes energy consumption directly.

Going further the study suggests that the authorities in the E7 countries should continue to sustainably implement measures built to achieve environmentally friendly tourism which effect is already improving the quality of the environs. Regulatory measures to improve energy conservation and the proportion of clean energies in the energy portfolio should be introduced concerning policy impacts. E7 policymakers should fund researchers and academic organizations focusing on gradual energy conservation. Since the impact on tourism is very small, further steps can be taken to improve the environmental impacts of the tourism industry. The funding and acceptance of bicycle-oriented tourism as a substitute for motor and ecological transport should be encouraged. This can be attained through the use of alternatively sustainable transport like electric rail over air transportation which will reduce mobility within a specific tourism destination. These measures if carefully implemented will improve the natural habitat in a great measure. Energy-efficient and sustainable technology can be 
used and embraced further in the tourism industry. Thus, further programs to improve ecology friendly technology, particularly those relating to tourism, should be funded by the E7 authorities. In addition, considering the twin growth witnessed among economic growth and energy consumption, which causes environmental pollution. This disclosure is apparent in the need for a transition in the energy mix that pushes emissions to renewables and green energies, and for possible enactment of laws such as polluter pay principles, and to be an involved participant of environmental treaties. This prescription is aligned with the United Nations Sustainable Development Goals (UN-SDGs-7,8,12 and 13), which discuss concerns relating to sustainable and responsible energy use for sustainable economic development, including sustainable tourism. For future studies, analyzing alternate tourismrelated attributes, such as human capital, can also contribute to change in the E7 countries, although inadequate data are currently available at the local level within these countries.

\section{REFERENCE}


Adedoyin, F. F., Alola, A. A., \& Bekun, F. V. (2020a). An assessment of environmental sustainability corridor: The role of economic expansion and research and development in EU countries. Science of the Total Environment, 136726.

Adedoyin, F. F., Gumede, M. I., Bekun, F. V., Etokakpan, M. U., \& Balsalobre-lorente, D. (2020b). Modelling coal rent, economic growth and CO2 emissions: Does regulatory quality matter in BRICS economies? Science of the Total Environment, 710, 136284.

Ajide, K. B., \& Adeniyi, O. (2010). FDI and the environment in developing economies: evidence from Nigeria. Environmental Research Journal, 4(4), 291-297.

Akpan, G.E. and Akpan, U.F. (2012), "Electricity consumption, carbon emissions and economic growth in Nigeria", International Journal of Energy Economics and Policy, Vol. 2 No. 4, pp. 292-306.

Alam, M.S., \& Paramati, S.R. (2016). The impact of tourism on income inequality in developing economies: Does Kuznets curve hypothesis exist? Annals of Tourism Research, 61, 111126.

Ali, W., Abdullah, A. and Azam, M. (2017a), "The dynamic relationship between structural change and CO2 emissions in Malaysia: a cointegrating approach", Environmental Science and Pollution Research, Vol. 24 No. 14, pp. 12723-12739.

Ali, W., Abdullah, A. and Azam, M. (2017a), "The dynamic relationship between structural change and CO2 emissions in Malaysia: a co-integrating approach", Environmental Science and Pollution Research, Vol. 24 No. 14, pp. 12723-12739

Ali, W., Abdullah, A. and Azam, M. (2017b), "Re-visiting the environmental Kuznets curve hypothesis for Malaysia: fresh evidence from ARDL bounds testing approach”, Renewable and Sustainable Energy Reviews, Vol. 77, pp. 990-1000.

Ali, W., Abdullah, A. and Azam, M. (2017b), "Re-visiting the environmental Kuznets curve hypothesis for Malaysia: fresh evidence from ARDL bounds testing approach”, Renewable and Sustainable Energy Reviews, Vol. 77, pp. 990-1000.

Al-Mulali, U., Fereidouni, H. G., and Mohammed, A. H. (2015). The effect of tourism arrival on CO2 emissions from transportation sector. Anatolia 26, 230-243. doi:10.1080/13032917.2014.934701

Al-Mulali, U., Ozturk, I., and Lean, H. H. (2015). The influence of economic growth, urbanization, 
trade openness, financial development, and renewable energy on pollution in Europe. Natural Hazards 79, 621-644. doi:10.1007/ s11069-015-1865-9

Anatasia, V. (2015). The causal relationship between GDP, exports, consumption, and CO2 in Thailand and Malaysia. International Journal of Economic Perspectives, 9.

Andriotis, K., and Vaughan, D. R. (2004). The tourism workforce and policy: Exploring the assumptions using Crete as the case study. Current Issues in Tourism, 7(1), 66-87

Balaguer, J., and Cantavella-Jorda, M. (2002). Tourism as a long-run economic growth factor: The Spanish case. Applied Economics, 34(7), 877-884.

Balsalobre-Lorente, D., Driha, O. M., Bekun, F. V., \& Adedoyin, F. F. (2020). The asymmetric impact of air transport on economic growth in Spain: fresh evidence from the tourism-led growth hypothesis. Current Issues in Tourism, 1-17.

Bekun, F. V., Alola, A. A., \& Sarkodie, S. A. (2019a). Toward a sustainable environment: Nexus between $\mathrm{CO} 2$ emissions, resource rent, renewable and nonrenewable energy in 16-EU countries. Science of the Total Environment, 657, 1023-1029.

Bekun, F. V., Emir, F., \& Sarkodie, S. A. (2019b). Another look at the relationship between energy consumption, carbon dioxide emissions, and economic growth in South Africa. Science of the Total Environment, 655, 759-765.

Bekun, F. V., \& Gyamfi, B. A. (2020c). Rethinking the nexus between pollutant emission, financial development, renewable energy consumption and economic growth in G7 countries. SOCLAL, HUMAN AND ADMINISTRATIVE SCIENCES-II, 73.

Brida, J. G., and Risso, W. A. (2009). Tourism as a factor of long-run economic growth: An empirical analysis for Chile. European Journal of Tourism Research, 2, 178-185

Brida, J. G., Cortes-Jimenez, I., and Pulina, M. (2016). Has the tourism-led growth hypothesis been validated? A literature review. Current Issues in Tourism, 19(5), 394-43

de Vita, G., Katircioglu, S., Altinay, L., Fethi, S., \& Mercan, M. (2015). Revisiting the environmental Kuznets curve hypothesis in a tourism development context. Environmental Science and Pollution Research, 22, 16652-16663. doi:10.1007/s11356- 015-4861-4

Dogan, E., \& Aslan, A. (2017). Exploring the relationship among CO2 emissions, real GDP, energy consumption and tourism in the EU and candidate countries: Evidence from panel models robust to heterogeneity and cross-sectional dependence. Renewable and Sustainable Energy Reviews, 77, 239-245. 
Dogan, E., and Inglesi Lotz, R. (2017). Analyzing the effects of real income and biomass energy consumption on carbon dioxide (CO2) emissions: Empirical evidence from the panel of biomass-consuming countries. Energy, 138, 721-727. doi:10.1016/j.energy.2017.07.13

Dogan, E., and Seker, F. (2016a). An investigation on the determinants of carbon emissions for OECD countries: empirical evidence from panel models robust to heterogeneity and cross-sectional dependence. Environmental Science and Pollution Research, 23, 1464614655.doi:10.1007/s11356-016-6632-2

Dogan, E., and Seker, F. (2016b). Determinants of CO2 emissions in the European Union: The role of renewable and non-renewable energy. Renewable Energy, 94, 429-439. doi:10.1016/j.renene.2016.03.078

Dogan, E., and Seker, F. (2016c). The influence of real output, renewable and non-renewable energy, trade and financial development on carbon emissions in the top renewable energy countries. Renewable and Sustainable Energy Reviews, 60, 1074-1085. doi:10.1016/j.rser.2016.02.006

Durbarry, R. (2004). Tourism and economic growth: The case of Mauritius. Tourism Economics, 10(4), 389-401

Emir, F., \& Bekun, F. V. (2019). Energy intensity, carbon emissions, renewable energy, and economic growth nexus: new insights from Romania. Energy \& Environment, 30(3), 427443.

Etokakpan, M. U., Bekun, F. V., \& Abubakar, A. M. (2019). Examining the Tourism-Led Growth Hypothesis, Agricultural-Led Growth Hypothesis and Economic Growth in Top Agricultural Producing Economies. European Journal of Tourism Research, 21, 132-137.

Eyuboglu, S., and Eyuboglu, K. (2019). Tourism development and economic growth: an asymmetric panel causality test. Current Issues in Tourism

Fang, J., Gozgor, G., Lu, Z., \& Wu, W. (2019). Effects of the export product quality on carbon dioxide emissions: evidence from developing economies. Environmental Science and Pollution Research, 26(12), 12181-12193.

Gokmenoglu, K., and Taspinar, N. (2016). The relationship between Co2 emissions, energy consumption, economic growth and FDI: The case of Turkey. The Journal of International Trade \& Economic Development, 25(5), 706-723 
Gossling, S. (2002). Global environmental consequences of tourism. Global Environmental Change, 12(4), 283-302.

Gozgor, G. (2016). Are shocks to renewable energy consumption permanent or transitory? An empirical investigation for Brazil, China, and India. Renewable and Sustainable Energy Reviews, 66, 913-919.

Gozgor, G., \& Ongan, S. (2017). Economic policy uncertainty and tourism demand: Empirical evidence from the USA. International Journal of Tourism Research, 19(1), 99-106.

Gyamfi, B. A. Bein, A. M. \& Bekun, V. F. (2020a). Investigating the nexus between hydroelectricity energy, renewable energy, non-renewable energy consumption on output: evidence from E7 countries. Environmental Science and Pollution Research https://doi.org/10.1007/s11356020-08909-8.

Gyamfi, B. A., Bein, M. A., Ozturk, I., \& Bekun, F. V. (2020b). The moderating role of employment in an environmental Kuznets curve framework revisited in G7 countries. Indonesian Journal of Sustainability Accounting and Management, 4(2).

Gyamfi, B. A., Sarpong, S. Y., \& Bein, M. A. (2020c). The contribution of the anthropogenic impact of biomass utilization on ecological degradation: revisiting the G7 economies. Environmental Science and Pollution Research, 1-14.

Heidari, H., Katircioglu, S. T., and Saeidpour, L. (2015). Economic growth, CO2 emissions, and energy consumption in the five ASEAN countries. International Journal of Electrical Power and Energy Systems, 64, 785-791. doi:10.1016/j. ijepes.2014.07.081

Higham, J., Cohen, S. A., Cavaliere, C. T., Reis, A., and Finkler, W. (2016). Climate change, tourist air travel and radical emissions reduction. Journal of Cleaner Production, 111, $336-347$ http://www.unep.org/resourceefficiency/Portals/24147/scp/business/tourism/greenecon omy_tourism.pdf

Isik, C., Dogan, E., and Ongan, S. (2017). Analyzing the tourism-energy-growth nexus for the top 10 most-visited countries. Economies, 5(40), 1-13

Jebli, M. B., Youssef, S. B., and Ozturk, I. (2016). Testing environmental Kuznets curve hypothesis: The role of renewable and non-renewable energy consumption and trade in OECD countries. Ecological Indicators, 60, 824-831. doi:10.1016/j.ecolind.2015.08.031 
Jurdana, D. S., and Frleta, D. S. (2017). Satisfaction as a determinant of tourist expenditure. Current Issues in Tourism, 20(7), 691-704

Kalayci, S., and Koksal, C. (2015). The relationship between china's airway freight in terms of carbon-dioxide emission and export volume. International Journal of Economic Perspectives, 9, 2015.

Katircioglu, S. T. (2014a). International tourism, energy consumption, and environmental pollution: The case of Turkey. Renewable and Sustainable Energy Reviews, 36, 180-187.

Katircioglu, S. T. (2014b). Testing the tourism-induced EKC hypothesis: The case of Singapore. Economic Modelling, 41, 383-391

Katircioglu, S. T., and Taspinar, N. (2017). Testing the moderating role of financial development in an environmental Kuznets curve: Empirical evidence from Turkey. Renewable and Sustainable Energy, 68, 572-586. doi:10.1016/j. rser.2016.09.12

Katırcioglu, S., Fethi, S., Kalmaz, D. B., and Caglar, D. (2016). Interactions between energy consumption, international trade, and real income in Canada: An empirical investigation from a new version of the Solow growth model. International Journal of Green Energy, 13, 1059-1074. doi:10.1080/15435075.2016.1175348

Lee, J. W., \& Brahmasrene, T. (2013). Investigating the influence of tourism on economic growth and carbon emissions: Evidence from panel analysis of the European Union. Tourism management, 38, 69-76.

Leon, C. J., Arana, J. E., and Hernandez Aleman, A. (2014). CO2 Emissions and tourism in developed and less developed countries. Applied Economics Letters, 21, 1169-1173. doi:10.1080/13504851.2014.916376

Li, G., Wu, D. C., Zhou, M., \& Liu, A. (2019). The combination of interval forecasts in tourism. Annals of Tourism Research, 75, 363-378.

Li, H., Chen, J. L., Li, G., and Goh, C. (2016). Tourism and regional income inequality: Evidence from China. Annals of Tourism Research, 58, 81-99.

Llorca-Rodríguez, C. M., García-Fernández, R. M., and Casas-Jurado, A. C. (2018). Domestic versus inbound tourism in poverty reduction: Evidence from panel data. Current Issues in Tourism, 1-20.

Lluís Carrion-i-Silvestre, J., Del Barrio-Castro, T., \& López-Bazo, E. (2005). Breaking the panels: an application to the GDP per capita. The Econometrics Journal, 8(2), 159-175 

and tourism investments on international tourism: Evidence from the G20 countries. Journal of Business Economics and Management, 20(6), 1102-1120.

MacNeill, T., and Wozniak, D. (2018). The economic, social, and environmental impacts of cruise tourism. Tourism Management, 66, 387-404.

Meng, M. and Niu, D. (2011), "Modeling CO2 emissions from fossil fuel combustion using the logistic equation", Energy, Vol. 36 No. 5, pp. 3355-3359

Meng, W., Xu, L., Hu, B., Zhou, J., \& Wang, Z. (2016). Quantifying direct and indirect carbon dioxide emissions of the Chinese tourism industry. Journal of Cleaner Production, 126, 586-594.

Meng, W., Xu, L., Hu, B., Zhou, J., and Wang, Z. (2016). Quantifying direct and indirect carbon dioxide emissions of the Chinese tourism industry. Journal of Cleaner Production, 126, $586-594$

Ozturk, I., and Acaravci, A. (2010). CO2 emissions, energy consumption and economic growth in Turkey. Renewable and Sustainable Energy Reviews, 14, 3220-3225

Pao, H. T., \& Tsai, C. M. (2010, December). Determinants of CO 2 emissions in BRICs. In 2010 IEEE International Conference on Sustainable Energy Technologies (ICSET) (pp. 1-4). IEEE.

Paramati, S. R., Alam, M. S., and Chen, C.-F. (2017). The effects of tourism on economic growth and $\mathrm{CO} 2$ emissions: a comparison between developed and developing economies. Journal of Travel Research, 56, 712-724. doi:10. 1177/004728751666784

Paramati, S. R., Shahbaz, M., and Alam, M. S. (2017). Does tourism degrade environmental quality? A comparative study of Eastern and Western European Union. Transportation Research Part D: Transport and Environment, 50, 1-13. doi:10.1016/j.trd.2016.10.034

Paramati, S. R., Sinha, A., and Dogan, E. (2017). The significance of renewable energy use for economic output and environmental protection: evidence from the Next 11 developing economies. Environmental Science and Pollution Research, 24, 13546-13560. doi:10.1007/s11356-017-8985-6

Peeters, P., and Dubois, G. (2010). Tourism travel under climate change mitigation constraints. Journal of Transport Geography, 18, 447-457

Ragab, A. M., and Meis, S. (2016). Developing environmental performance measures for tourism using a Tourism Satellite Accounts approach: A pilot study of the accommodation Industry in Egypt. Journal of Sustainable Tourism, 24, 1007-1023. doi:10.1080/09669582.2015.1107078 
Raza, S. A., Sharif, A., Wong, W. K., and Karim, M. Z. A. (2016). Tourism development and environmental degradation in the United States: evidence from wavelet-based analysis. Current Issues in Tourism, 3500, 1-23. doi:10.1080/ 13683500.2016.1192587

Robaina-Alves, M., Moutinho, V., and Costa, R. (2013). Change in energy-related CO2 (carbon dioxide) emissions in Portuguese tourism: A decomposition analysis from 2000 to 2008. Journal of Cleaner Production, 111, 520-528. doi:10.1016/j.jclepro.2015.03.023

Roudi, S., Arasli, H., and Akadiri, S. S. (2018). New insights into an old issue-examining the influence of tourism on economic growth: Evidence from selected small island developing states. Current Issues in Tourism, 22(11), 1280-1300

Roxas, F. M. Y., Rivera, J. P. R., and Gutierrez, E. L. M. (2018). Framework for creating sustainable tourism using systems thinking. Current Issues in Tourism, 1-17

Saboori, B. and Sulaiman, J. (2013), "Environmental degradation, economic growth and energy consumption: evidence of the environmental Kuznets curve in Malaysia”, Energy Policy, Vol. 60, pp. 892-905

Saenz-de-Miera, O., and Rossello, J. (2014). Modeling tourism impacts on air pollution: The case study of PM10 in Mallorca. Tourism Management, 40, 273-281. doi:10.1016/j.tourman.2013.06.012

Sarkodie, S. A., Ackom, E., Bekun, F. V., \& Owusu, P. A. (2020). Energy-Climate-EconomyPopulation Nexus: An Empirical Analysis in Kenya, Senegal, and Eswatini. Sustainability, 12(15), 6202.

Sarpong, S. Y., Bein, M. A., Gyamfi, B. A., \& Sarkodie, S. A. (2020). The impact of tourism arrivals, tourism receipts and renewable energy consumption on quality of life: A panel study of Southern African region. Heliyon, 6(11), e05351.

Sbia, R., Shahbaz, M. and Hamdi, H. (2014), "A contribution of foreign direct investment, clean energy, trade openness, carbon emissions and economic growth to energy demand in UAE”, Economic Modelling, Vol. 36, pp. 191-197

Shafiei, S., \& Salim, R. A. (2014). Non-renewable and renewable energy consumption and CO2 emissions in OECD countries: A comparative analysis. Energy Policy, 66, 547-556. doi:10.1016/j.enpol.2013.10.064

Shahbaz, M., \& Sinha, A. (2019). Environmental Kuznets curve for CO2 emissions: a literature survey. Journal of Economic Studies. 
Sharif, A., Afshan, S., and Nisha, N. (2017). Impact of tourism on CO2 emission: Evidence from Pakistan. Asia Pacific Journal of Tourism Research, 22(4), 408-421

Shi, H., Li, X., Zhang, H., Liu, X., Li, T., and Zhong, Z. (2019). Global difference in the relationships between tourism, economic growth, CO2 emissions, and primary energy consumption. Current Issues in Tourism, 1-16.

Solarin, S. A. (2014). Tourist arrivals and macroeconomic determinants of CO2 emissions in Malaysia. Anatolia, 25, 228-241. doi:10.1080/13032917.2013.868364

Tang, C. F., and Tan, E. C. (2013). How stable is the tourism-led growth hypothesis in Malaysia? Evidence from disaggregated tourism markets. Tourism Management, 37, 52-57. doi:10.1016/j.tourman.2012.12.014

Tang, C. F., and Tan, E. C. (2013). How stable is the tourism-led growth hypothesis in Malaysia? Evidence from disaggregated tourism markets. Tourism Management, 37, 52-57. doi:10.1016/j.tourman.2012.12.014

United Nations Environment Program (2011) Tourism: investing in energy and resource efficiency.

Walpole, M. J, and Goodwin, H. J. (2000). Local economic impacts of dragon tourism in Indonesia. Annals of Tourism Research, 27(3), 559-576.

World Trade Tourism council. (2016). World Trade \&Tourism Council, 1-10. https://doi.org/https://tool.wttc.org/

Yorucu, V. (2016). Growth impact of CO2 emissions caused by tourist arrivals in Turkey. International Journal of Climate Change Strategies and Management, 8(1), 19-3

Zhang, L., \& Gao, J. (2016). Exploring the effects of international tourism on China's economic growth, energy consumption and environmental pollution: Evidence from a regional panel analysis. Renewable and Sustainable Energy Reviews, 53, 225-234.

Zhang, X.P. and Cheng, X.M. (2009), "Energy consumption, carbon emissions and economic growth in China”, Ecological Economics, Vol. 68 No. 10, pp. 2706-2712.

Zurub, H., Ionescu, A., and Constantin, V. D. (2015). Measuring the economic impact of tourism in European emerging markets. Procedia Economics and Finance, 32, 95-102. 
Appendix

Carrion-i-Silvestre -Panel stationarity that allows for the presence of multiple structural breaks

\begin{tabular}{|c|c|c|c|c|c|c|}
\hline \multicolumn{2}{|c|}{ Variable name } & \multicolumn{3}{|c|}{$\begin{array}{l}\text { Bootstrapt critical values } \\
\mathrm{LnCO}_{2}\end{array}$} & \multirow[b]{2}{*}{0.990} & \multirow[b]{2}{*}{ \# of } \\
\hline & section & KPSS test & 0.900 & 0.950 & & \\
\hline & & & & & & $\begin{array}{l}\text { break } \\
\text { years }\end{array}$ \\
\hline 1 & 0.068 & 1.048 & 1.576 & 3.769 & 1 & 2010 \\
\hline 2 & 0.617 & 1.069 & 1.704 & 3.503 & 1 & 2010 \\
\hline 3 & 0.824 & 1.057 & 1.599 & 3.512 & 1 & 2010 \\
\hline & & & & & & 2010 \\
\hline 4 & 0.44 & 1.088 & 1.595 & 3.477 & 2 & 2013 \\
\hline 5 & 0.004 & 1.121 & 1.755 & 3.661 & 1 & 2010 \\
\hline 6 & 0.545 & 1.133 & 1.74 & 4.012 & 1 & $\begin{array}{l}2010 \\
2009\end{array}$ \\
\hline 7 & 0.403 & 1.137 & 1.662 & 3.236 & 2 & 2012 \\
\hline
\end{tabular}

Variable name LnEU

Bootstrapt critical values

\begin{tabular}{lllll}
\hline $\begin{array}{l}\text { Cross-section } \\
\text { breaks }\end{array}$ & KPSS test & 0.900 & 0.950 & 0.990 \\
\hline
\end{tabular}

\begin{tabular}{rrrrrrl}
\hline 1 & & & & \multicolumn{2}{l}{ break years } \\
2 & 0.114 & 1.128 & 1.557 & 3.215 & 2 & 20102013 \\
3 & 0.108 & 1.113 & 1.561 & 3.014 & 2 & 20102013 \\
4 & 0.098 & 1.1 & 1.537 & 3.102 & 2 & 20102013 \\
5 & 0.47 & 1.111 & 1.672 & 3.259 & 2 & 20102013 \\
6 & 0.493 & 1.122 & 1.644 & 3.503 & 2 & 20102012 \\
7 & 0.456 & 1.139 & 1.698 & 3.646 & 2 & 20102011 \\
& 0.507 & 1.143 & 1.633 & 3.31 & 2 & 20092012
\end{tabular}

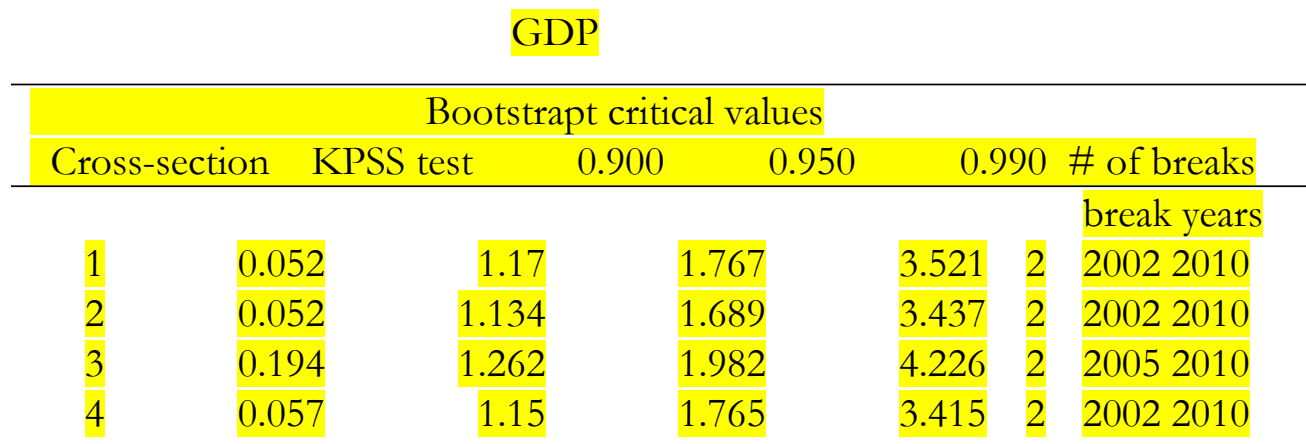




$\begin{array}{rrrrrrr}5 & 0.329 & 1.099 & 1.686 & 3.339 & 2 & 20022010 \\ 6 & 0.334 & 1.054 & 1.591 & 3.154 & 2 & 20012010 \\ 7 & 0.368 & 1.085 & 1.61 & 3.187 & 2 & 20012009\end{array}$

\section{INVT}

\begin{tabular}{lrrrrrr}
\hline \multicolumn{7}{c}{ Bootstrapt critical values } \\
\multicolumn{2}{c}{$\begin{array}{l}\text { Cross-section } \\
\text { of breaks }\end{array}$} & KPSS test & 0.900 & 0.950 & 0.990 & $\#$ \\
1 & 0.287 & 1.005 & 1.539 & 3.286 & 0 & \\
2 & 0.384 & 0.98 & 1.542 & 3.102 & 0 & \\
3 & 0.677 & 1.042 & 1.628 & 3.754 & 0 & \\
4 & 0.363 & 0.958 & 1.533 & 3.197 & 0 \\
5 & 0.229 & 1.016 & 1.574 & 3.558 & 0 \\
6 & 0.485 & 1.032 & 1.628 & 3.521 & 0 \\
7 & 0.128 & 0.993 & 1.525 & 3.11 & 0 \\
\hline
\end{tabular}

\section{TR}

\begin{tabular}{|c|c|c|c|c|c|c|}
\hline \multicolumn{7}{|c|}{ Bootstrapt critical values } \\
\hline & ection & test & 0.900 & & & \# of breaks \\
\hline 1 & 0.179 & 1.051 & & 1.601 & 3.87 & 70 \\
\hline 2 & 1.861 & 0.999 & & 1.461 & 3.677 & 70 \\
\hline 3 & 0.488 & 2.377 & & 3.107 & 5.329 & 92 \\
\hline 4 & 0.334 & 1.006 & & 1.56 & 3.524 & 40 \\
\hline 5 & 0.361 & 1.008 & & 1.614 & 3.91 & 10 \\
\hline 6 & 0.262 & 1.02 & & 1.622 & 3.846 & $\begin{array}{ll}6 & 0\end{array}$ \\
\hline 7 & 0.103 & 1.018 & & 1.601 & 3.621 & 10 \\
\hline
\end{tabular}

